Ивона 3. Илић

Универзитет у Новом Саду

Филозофски факултет

ivona.ilic1@yahoo.com doi: 10.19090/zjik.2018.11-26

UDK 811.163.41’366.582.6

оригинални научни рад

\title{
ПЛУСКВАМПЕРФЕКАТ У КООРДИНИРАНИМ РЕЧЕНИЦАМА У САВРЕМЕНОМ СТАНДАРДНОМ СРПСКОМ ЈЕЗИКУ: НА ПРИМЕРИМА ИЗ БЕЛЕТРИСТИЧКОГ ФУНКЦИОНАЛНОГ СТИЛА *
}

САЖЕТАК: У раду се анализирају координиране копулативне и адверзативне двопредикатске и вишепредикатске сентенцијалне структуре у којима плусквамперфекат има функцију предиката. Пажња ће бити усмерена ка примерима ексцерпираним из текстова који припадају белетристичком функционалном стилу савременог стандардног српског језика. Најпре ће бити изложено образложење теоријско-методолошког полазишта, те сагледани основни циљеви истраживања и корпус на којем ће анализа бити спроведена, да би се потом приступило сагледавању основних карактеристика плусквамперфекта као наративног средства у датом типу реченичних структура.

Кључне речи: координација, координиране копулативне реченице, координиране адверзативне реченице, плусквамперфекат, тип глаголске ситуације.

\section{1.УВОД: ПРЕДМЕТ, ЦИЉЕВИ И КОРПУС ИСТРАЖИВАҢА}

1.1. Предмет овога рада јесу дистрибутивне и функционалне карактеристике плусквамперфекта у наративном дискурсу савременог стандардног српског језика, при чему ће дати проблем бити разматран у координираним копулативним и адверзативним двопредикатским и вишепредикатским сентенцијалним структурама у којима наведени глаголски облик има функцију предиката. Будући да плусквамперфекат, уз футур 2, припада тзв. везаним глаголским облицима (Ивић 1958), те да су његове синтаксичко-семантичке улоге испитиване у реченичном комплексу са темпоралном клаузом (в. Antonić 2001), као најчешћим доменом његове употребе, у овом раду трагаће се за синтаксичким и семантичким карактеристикама плусквамперфекта у структурама које се састоје „од предикацијских делова који су истог синтаксичког ранга и нису у односу синтаксичке зависности једног дела од другог, а значе однос повезаности двеју ситуација без везничког истицања њихове лексички исказиве различитости" 
(Пипер 2018: 41). Основна хипотеза којом је мотивисан избор емпиријских података на којима ће истраживање бити спроведено јесте да ће успостављени координацијски однос наметати одређене правилности у погледу употребе овог глаголског облика које нису забележене у реченичним комплексима са субординацијом. Као што ће анализа показати, у највећем броју случајева овај глаголски облик фигурира као предикат само једне реченице, мада су регистровани и примери симетрије. ${ }^{1}$ Највише пажње биће посвећено конгруенцији глаголских облика, ${ }^{2}$ конфигурацији типова глаголске ситуације, те улози плусквамперфекта у појединачним реченицама.

1.2. Због својих морфолошких, синтаксичких и семантичких специфичности, овај глаголски облик неретко је био предмет пажње истраживача у србистици, било да је уочена његова улога као сигнала антериорности приликом темпоралне идентификације локационооријентационог типа (Antonić 2001: 110-125), било да се анализира као наративно средство (Радовановић 1969; Курешевић 2009), да је његова употреба сагледана у језику одређеног писца (Радовановић 1975), да је анализиран у укупном систему глаголских облика (Ивић 1958), или да је уочена одговарајућа, до тада незапажена, функција (Ивић 1980). Синтетизован опис плусквамперфекат добија у Синтакси савременога српског језика: проста реченица (Танасић 2005: 411-423). У најрецентнијој студији која се једним својим делом бави и употребом плусквамперфекта, проучавајући дати глаголски облик из перспективе категорије таксиса ${ }^{3}$ Љ. Поповић указује на низ

* Овај рад је проистекао из семинарског рада насталог под менторством проф. др Владиславе Ружић и доц. др Јелене Ајџановић у оквиру курса Синтакса функционалних стилова на мастерским студијама на Одсеку за српски језик и лингвистику Филозофског факултета Универзитета у Новом Саду. Захваљујем професоркама и анонимним рецензентима, чији су значајни коментари и запажања допринели квалитету овога рада.

1 Под симетријом у овом случају подразумевају се примери у којима се плусквамперфекат јавља у функцији предиката обе реченице које су у координираном односу, дакле [плусквамперфекат + плусквамперфекат].

2 Термин конгруениија глаголских облика користи И. Антонић у својој студији Vremenska rečenica (2001). Под овим појмом подразумева се слагање глаголских облика у двема корелативним предикацијама.

3 Људмила Поповић таксис дефинише као функционално-семантичку категорију „која обухвата средства морфолошког, лексичко-семантичког и синтаксичког нивоа у функцији исказивања узајамне темпоралне оријентације у реченици главне и зависне 
функција које овај глаголски облик може остварити . Поред (1) таксисне, ауторка издваја и следеће семантичке и дискурсне функције плусквамперфекта: (2) означавање резултата у прошлости, (3) исказивање прекинуте започете ситуације, (4) дезактуализација резултата претходне радње, (5) ретроспективна актуализација, (6) топикализација, (7) дигресивна функција (Поповић 2012б: 36-37). На овај начин, ауторка је, полазећи од текста и улоге коју поменуте функције имају на плану кохезије, раздвојила поједине функције које су у ранијој литератури биле подвођене под један појам и на тај начин извршила прецизнију класификацију. Детаљан преглед истраживања посвећених проблематици овог глаголског облика у типолошкој, славистичкој и србистичкој литератури изложен је у Поповић 2012a, те се овом приликом нећемо детаљније освртати на постојеће студије.

1.3. Циљеви овога истраживања огледају се у (а) уочавању функције плусквамперфекта у координираним копулативним и адверзативним двопредикатским и вишепредикатским реченицама, (б) утврђивању конгруенцијских веза плусквамперфекта са другим глаголским облицима у датим сентенцијалним структурама, (в) утврђивању евентуалних сличности и разлика у погледу конгруенције глаголских облика између поменута два типа реченица, као и (г) утврђивању типова глаголске ситуације у појединачним реченицама и њихове конфигурације на нивоу двопредикатских и вишепредикатских реченица, те (д) запажању евентуалних правилности у координираним структурама.

1.4. Корпус обухвата 76 примера, ${ }^{4}$ ексцерпираних са 160 страница прозног текста, прецизније, из три кратка романа Улица Молерова, Врачар и Улица Коларчева, обједињених у роман Врачар Светлане Велмар-Јанковић. Свесни смо да би за извођење општијих закључака о употреби појединачних

ситуације, које могу бити временски подударне и неподударне - симултане и асимултане" (Поповић 2012: 20).

${ }^{4}$ Координиране копулативне и адверзативне структуре јављају се у 13 примера. Овом приликом наводи се укупан број примера у којима је плусквамперфекат регистрован у сложеној реченици будући да овај квантитативни податак може бити од значаја приликом описа дистрибутивних карактеристика разматраног глаголског облика у наративном типу дискурса, те указати на његову знатно чешћу фреквентност у реченичном комплексу са интеграцијом, под којим се подразумева реченица у чију је структуру интегрисана барем једна (субординирана) клауза (Ivić 1963, наведено према Antonić 2001: 368). 
глаголских времена у сложеним реченицама у којима се успоставља однос координације неопходно било сагледати дату проблематику на знатно обимнијем корпусу, те је ово истраживање само почетни корак у том правцу. Избор извора за формирање корпуса резултат је тежње да се жељена проблематика сагледа у проседеу писца који својим стваралаштвом припада и временским и територијалним оквирима савременог стандардног српског језика. Наиме, анализирани прозни текстови настали су у периоду од 1989. до 1991. године, те не би требало очекивати да је до садашњег тренутка дошло до промена које би могле утицати на дистрибутивне и функционалне карактеристике разматраног глаголског облика, док ауторку романа можемо с пуним правом сматрати представником тзв. „доброг стила” у књижевности. Важно је напоменути и да смо се за анализирање плусквамперфекта у белетристичком функционалном стилу определили сматрајући да ће најпогоднији извор за ексцерпцију сложених реченичних структура наративног типа бити управо поменути функционални стил, будући да се „под њим подразумева богат и изнијансиран стил" (Klikovac 2008: 133), те да се у њему „употребљавају неке речи, изрази и, можда, творбена и синтаксичка средства која се не употребљавају ни у једном другом функционалном стилу" (Klikovac 2008: 133).

\section{2. АНАЛИЗА ГРАЪЕ}

У оквиру првога одељка усмерићемо своју пажњу ка употреби глаголског облика који је непосредни предмет овога истраживања најпре у координираним копулативним сентенцијалним структурама, указаћемо на његове функције у овом типу реченичних структура са посебним освртом на конгруенцију глаголских облика и конфигурацију типова глаголске ситуације, а потом, у оквиру другога одељка, координираном адверзативним сентенцијалним структурама.

Термин тип глаголске ситуащије дефинисао је П. Новаков у својој студији Глаголски вид и тип глаголске ситуације у енглеском и српском језику (2005). Аутор разликује четири типа глаголске ситуације, и то активности, ${ }^{5}$

\footnotetext{
${ }^{5}$ Како аутор наводи „,активности су глаголске ситуације које подразумевају структуру са сукцесивним сегментима, при чему су сви сегменти једнаки по квалитету. Пошто су једнаки, не постоји посебан сегмент који би означавао крај ситуације, па је сваки појединачан довољан да означи квалитет целе ситуације” (Новаков 2005: 27). Као
} 
$c m a њ a,{ }^{6}$ остварењ $a^{7}$ и достигнућ $a,{ }^{8}$ класификована на основу микрообележја стативност, трајање и иииь, при чему активности одликују микрообележја [стативност $(-)$, трајање $(+)$, циљ $(-)$ ], стања [стативност $(+)$, трајање $(+)$, циљ $(-)$ ], остварења [стативност $(-)$, трајање $(+)$, циљ $(+)$ ], а достигнућа микрообележја [стативност (-), трајање $(-)$, циљ $(+)$ ] (Новаков 2005: 30). Како запажа И. Антонић „данас бисмо могли рећи да се заправо тај појам односи на незаобилазни сегмент укупне прагматичке ситуације који се тиче природе човекових активности, његових стања и збивања у природној околини, односно човековог поимања апстрактних операција" (Антонић 2006: 383).

\section{1. Координиране копулативне сентенцијалне структуре}

2.1.1. У координираној копулативној двопредикатској сентенцијалној структури, насталој синдетским синтаксичко-семантичким поступком везивања, експлицирањем везника $u$ као прототипског копулативног координатора, плусквамперфекат има функцију исказивања хронолошког тока догађаја, ${ }^{9}$ а у оквиру ње, као подфункцију, сигналну функцију антериорности.

типичне глаголе којима се репрезентује овај тип глаголске ситуације аутор издваја лексеме run (трчати), walk (ходати), swim (пливати).

${ }^{6}$ Стања су дефинисана као „ситуације без развоја и динамичних сегмената, па означавају само постојање одређене особине или ситуације у времену. Овај тип глаголске ситуације не подразумева никакав процес, већ само трајање упоредо с временом" (Новаков 2005: 28). Типични представници овога типа глаголске ситуације јесу глаголи know (знати), believe (веровати), love (волети).

7 Под остварењем се подразумева тип глаголске ситуације „који нема хомогену структуру, пошто постоје сегменти који обухватају ток ситуације, али и сегмент који означава крајњу тачку у којој се ситуација природно завршава" (Новаков 2005: 28 29). Аутор издваја следеће глаголске изразе: run a mile (претрчати миљу), draw a circle (наиртати круг), paint a picture (насликати слику).

${ }^{8}$ П. Новаков достигнућа одређује као „ситуацију која обухвата само један тренутак у којем се цела ситуација и реализује” (Новаков 2005: 29), издвајајући као карактеристичне глаголе find (наћu), kick (шутнути), lose (изгубити).

9 Љ. Поповић истиче да „на хронолошки след ситуација указује плусквамперфекат и у напоредносложеним реченицама, где означава радњу која је временски претходила ситуацији исказаној претеритом у функцији предиката друге реченице" (Поповић 2012a: 125). Ауторка наводи пример копулативних координираних реченица у српском језику, а осврће се и на функцију прекинуте ситуације која је „типична за плусквамперфекат у украјинским напоредносложеним реченицама са реализованим поредбено-супротним односом" (Поповић 2012a: 128), наглашавајући да се та функција, типична за украјински језик, у српском језику јавља ређе (Поповић 2012а: 129). Поред функције прекинуте прошле ситуације, у украјинском језику 
У овој минималној двочланој целини, дати глаголски облик конгруира са перфектом. Са становишта типа глаголске ситуације може се идентификовати конфигурација [СТАњЕ - ОСТВАРЕЊЕ], будући да предикација формализована перфектом глагола бити може бити поимана искључиво као трајање у времену, без могућности да се идентификују промена или развој, док глагол тећи префиксацијом мења свој основни тип глаголске ситуације, активност, и постаје остварење. Одредба две године указује како на трајање ситуације, односно темпоралну квантификацију [Колико дуго је протекло од смрти Хаџи-Рувимове?] тако и на њену ограниченост.

(1) Опет је био јануар и биле су протекле две године од смрти ХаџиРувимове. (Светлана Велмар-Јанковић, Врачар: 43);

Исту функцију плусквамперфекат има и у координираним копулативним вишепредикатским сентенцијалним структурама, означавајући, по правилу, иницијалну радњу, антериорну свим осталим радњама, те се и у овом случају може говорити о функцији исказивања хронолошког тока догађаја уз присутну сигналну функцију антериорности. Као и у претходном случају, конгруенција се остварује са перфектом (2-3), али и са плусквамперфектом у асиндетском делу (3). У примеру (2) четири типа глаголске ситуације нижу се на следећи начин [ДОСТИГНУЋЕ ДОСТИГНУЋЕ - ОСТВАРЕЊЕ - ДОСТИГНУЋЕ]. Будући да префикс на-

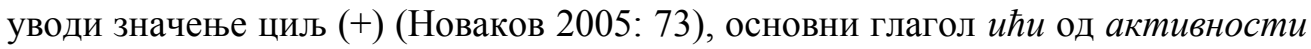
постаје достигнуће. ${ }^{10}$ Глаголске лексеме затећи и заноћити такође

плускавмперфекат у напоредносложеним реченицама може имати и функцију поништења резултата прошле радње (Поповић 2012a: 131). Будући да, по ауторкином мишљењу, а следствено приступу В. С. Храковског, координиране реченице остају изван оквира категорије таксиса, разумљиво је што им у овоме раду није посвећено више пажње.

10 У начелу, префиксацијом формантом на- основни глагол који представља активност могао би постати остварење или достигнуће, а основни критериј за њихово разликовање јесте обележје трајања (Новаков 2005: 73). У овом случају, као додатни индикатор да је у питању наведени тип глаголске ситуације са присутним обележјем трајање (-) појављује се прилог изненадно као показатељ значења изненадног појављивања у времену. И. Антонић у истраживању посвећеном прилошким лексемама изненада, одједном, одједанпут, наједанпут, наједном, одједаред, нагло, неочекивано, непредвиђено, напрасно као индикаторима поменутог значења наглашава да је у најужем смислу значење изненадног појављивања везано „за временску димензију која упућује на то да се реченична предикација појављује у 
префиксацијом мењају тип глаголске ситуације основног глагола и од активности постају достигнућа, при чему глагол затећи означава ситуацију која се у потпуности завршава чим започне, док глагол заноћити указује на радњу која је у целости извршена. ${ }^{11}$ Са друге стране, активност палити, додавањем форманта по- постаје остварење и означава ,трајање процеса до остварења циља" (Новаков 2005: 76).

(2) Турци су били изненадно наишли у ваљевску нахију, затекли је без одбране јер је сва српска војска била у опсади код Шапца, попалили што су стигли и заноћили на Чучугама (Светлана Велмар-Јанковић, Врачар: 44);

У вишепредикатској сентенцијалној структури (3) насталој комбинацијом асиндетског и синдетског синтаксичко-семантичког поступка везивања остварени су следећи типови глаголске ситуације [ОСТВАРЕЊЕ ОСТВАРЕњЕ - АКТИВНОСТ - АКТИВНОСТ].

(3) [...] био је склепао нека мала кола, упрегао у њих своје ждребе од кога се ни иначе није раздвајао, па је свакога дана развозио и продавао, избеглицама, рибу која је била не само свежа него и јефтина (Светлана Велмар-Јанковић, Врачар: 131);

Дата функција овог глаголског облика регистрована је и у координираним копулативним двопредикатским сентенцијалним структурама, насталим синдетским синтаксичко-семантичким поступком везивања, експлицирањем везника $a$. Премда се ова везничка јединица најчешће сврстава у групу адверзативних везника којима, на основу одређених својих употреба, несумњиво и припада, у следећим компонованим реченичним структурама нема индиција супротног односа, већ се, као у разматраним случајевима, реферише о хронолошком следу догађаја, при чему плусквамперфекат увек

\footnotetext{
једном тренутку на временској оси, али без компоненте временске локализације, и са импликацијом обележја трајање (-), чиме је искључена временска квантификација типа лонгитудиналност, али и временска квантификација типа брзина појављивања, на шта би евентуално могло да упути управо обележје трајање (-): 'изненада - одједном у тренутку - у трену"” (Антонић 2015: 148).

11 Овај глагол у Речнику Матице српске дефинисан је на следећи начин: зано̀ћити, за̀ноћйм свр. 1. затећи се негде кад настане ноћ, преноћити: на Златибору (РМС 2011: 388).
} 
означава иницијалну ситуацију (4-5), те и у овом случају има сигналну функцију антериорности. Под иницијалном ситуацијом у примеру (4) подразумевамо први, експлицирани део предиката [је био измакао], али и други, елидирани део, који се несумњиво може реконструисати. Међутим, по нашем суду, координиране реченице не располажу тако широким системом показатеља односа симултаности као што је то случај код субординиране темпоралне клаузе, ${ }^{12}$ те је једини сигнал симултаног односа у примеру (4) социјативна предлошко-падежна форма у инструменталу [са њим]. ${ }^{13}$ Ова, дакле, иницијална ситуација налази се у односу антериорности према постериорној ситуацији о којој реферише консекутивна клауза чији је предикат формализован перфектом, те можемо закључити да се у случају симетрије у конгруенцији [плусквамперфекат + плусквамперфекат] ради о симултаном временском односу, али су ове две ситуације у односу антериорности према радњи исказаној перфектом. У том смислу, можемо говорити о конгруенцији плусквамперфекта и плусквамперфекта, као и о конгруенцији плусквамперфекта и перфекта. У погледу типа глаголске ситуације, забележене су следеће конфигурације (4) [ДОСТИГНУЋЕ [ДОСТИГНУЋЕ] - АКТИВНОСТ] и (5) [ОСТВАРЕњЕ - ДОСТИГНУЋЕ],

(4) Млади Михаило већ је био измакао Вучићу преко Саве, у Аустрију, а са њим [су били измакли]14 и сви, до тада још у Београду заостали Обреновићи, тако да се Господар Тома сад мирно могао да бави изгласавањем новог владара Србије (Светлана Велмар-Јанковић, Врачар: 116);

2 И. Антонић на плану симултаности разликује симултаност линеарну потпуну, симултаност линеарну делимичну и симултаност пунктуалну са низом подтипова условљених различитим аспекатским конфигурацијама у матричној и субординираној предикацији (Antonić 2001: 90-110). Међутим, координиране реченице, сасвим очекивано, не могу покрити сва значења која су доступна субординираним темпоралним клаузама. Овакве примере наводимо зато што сматрамо да од помоћи приликом сагледавања природе синтаксичко-семантичког односа координације, који још увек није добио целовит опис не само у славистичкој, него ни у индоевропској и типолошкој перспективи, може послужити његово поређење са стањем у систему субординираних клауза.

13 У питању је инструментал друштва, односно социјатив посредног типа (Антонић 2005: 268).

${ }^{14}$ Угластим заградама упућује се на елидирани предикат. 
(5) [...] прекјуче је био стигао из Студенице у Боговађу а малочас ступио у Нешковића двориште са књигом у руци (Светлана Велмар-Јанковић, Bрачар: 15);

2.1.2. У координираној копулативној двопредикатској сентенцијалној структури, насталој синдетским синтаксичко-семантичким поступком везивања, експлицирањем везника $u$, којом се исказује узрочно-последични семантички однос, предикација формализована плусквамперфектом јесте последица, док је предикација формализована перфектом узрок. У овом случају остварује се делимична симултаност консекутивне и каузалне предикације, при чему се симултаност постепено успоставља током трајања каузалне предикације. Важно је нагласити да у овом случају на интерпретацију успостављеног узрочно-последичног односа утиче укупна семантика двеју реченица које творе координирани однос, а не употреба појединачних глаголских облика. За разлику од претходно разматраних примера, радња исказана перфектом претходи радњи исказаној плусквамперфектом. Уз то, може се идентификовати следећа конфигурација типова глаголске ситуације: [ОСТВАРЕњЕ - [ОСТВАРЕњЕ] - ОСТВАРЕњЕ], при чему је у случају глагола смељивати се присутно и значење итеративност $(+)$ :

(6) [...] успон се смењивао са падом а пад [се смењивао] са успоном, и он је на те обрте сасвим био навикао (Светлана Велмар-Јанковић, Врачар: 117); $\rightarrow$ ЗАТО ШТО/ ПОШТО се успон смењивао са падом а пад са успоном, он је на те обрте сасвим био навикао / Успон се смењивао са падом а пад са успоном ТАКО ДА/ ПА је он на те обрте сасвим био навикао.]

Иако би структура са употребљеним перфектом уместо плусквамперфекта била сасвим граматична:

(6a) [...] успон се смењивао са падом а пад [се смењивао] са успоном, и он је на те обрте сасвим навикао.

... чини се да у овом случају на употребу плусквамперфекта утиче шири језички контекст, прецизније, предикација која следи након дате структуре, што нам даје довољно аргумената за тврдњу да употребу овога глаголског облика треба додатно испитати на међуреченичном нивоу. 
Уз то, узрочно-последични однос може бити исказан и координираном копулативном вишепредикатским сентенцијалним структурама, насталим асиндетским синтаксичко-семантичким поступком везивања. Као и у претходном примеру, плусквамперфекат конгруира са перфектом, док је у погледу типа глаголске ситуације остварена конфигурација [ОСТВАРЕњЕ ОСТВАРЕњЕ - АКТИВНОСТ]:

(7) Одбрана је била пропала, Србија из Буне [је била] скршена, војводе су бежале за Карађорђем, безглаво, у Срем, у Аустрију (Светлана ВелмарЈанковић, Врачар: 73); [ $\rightarrow \ldots$ И ЗАТО/ ПА су војводе бежале за Карађорђем, безглаво, у Срем, у Аустрију.]

2.1.3. На основу претходне анализе можемо закључити да употребу плусквамперфекта у координираним копулативним сентенцијалним структурама одликује (а) функција исказивања хронолошког тока догађаја, као и (a') сигнална функција антериорности. Са становишта конгруенције глаголских облика, плусквамперфекат у већини случајева конгруира са перфектом, при чему се између радњи формализованих овим глаголским облицима успоставља антериорно-постериорни однос. Са друге стране, у ситуацијама симетричне употребе, плусквамперфекат остварује (а") функцију симултаности. Исте функционалне и дистрибутивне карактеристике овај глаголски облик испољава у успостављеним узрочно-последичним односима, при чему може припадати реченичној структури којом се исказује последица (6), али и реченичној структури којом се исказује узрок (7), конгруирајући у оба случаја са перфектом. У погледу типа глаголске ситуације, предикација означена плусквамперфектом у разматраном корпусу остварује се као остварење или као достигнуће, а то су управо они типови глаголске ситуације које у српском језику покрива значење перфективности. ${ }^{15}$

\section{2. Координиране адверзативне сентениијалне структуре}

2.2.1. Функцију исказивања хронолошког тока догађаја уз сигналну функцију антериорности плусквамперфекат има и у координираним адверзативним двопредикатским сентенцијалним структурама, насталим

\footnotetext{
${ }^{15}$ Међутим, треба напоменути да перфективност, иако чешћи, није и једини могући видски лик овог глаголског облика у српском језику, што показује Љ. Поповић (2012a).
} 
асиндетским или синдетским синтаксичко-семантичким поступком везивања експлицирањем везника $a$. Међутим, дата везничка јединица само је један од показатеља адверзативности, свакако не одређујући. Да бисмо одговарајућу компоновану структуру сматрали адверзативном, семантичка вредност једне реченице у њеном саставу мора бити у несумњивом односу, у најширем смислу схваћене, супротности према другој координираној реченици. Тако су у примеру (1) антериорна радња исказана плусквамперфектом и постериорна радња исказана перфектом међусобно супротстављене (неко је био одликован почастима, али га сада бране од нечасности). У погледу типа глаголске ситуације може се идентификовати конфигурација [ДОСТИГНУЋЕ АКТИВНОСТ].

(1) Пре пет година, у јануару 1807, Карађорђе га је био одликовао многим почастима; сада, после пет година, бранио га је од многих нечасности (Светлана Велмар-Јанковић, Врачар: 54);

На исти начин исказан је и временски однос у примеру (2). Будући да у овом случају можемо идентификовати симетрију у конгруенцији глаголских облика [плусквамперфекат + плусквамперфекат], приликом одређивања временског односа у виду морамо имати целокупну семантичку структуру двопредикатских адверзативних сентенцијалних форми. Тако ће, у датом примеру, постпонована реченица бити антериорна препонованој, будући да целокупна сложена структура указује на смењивање у времену (последња деценија осамнаестог века долази на измак, а деветнаести век ступа на праг времена), док се у погледу типа глаголске ситуације остварује конфигурација [ОСТВАРЕЊЕ - ОСТВАРЕЊЕ]. Премда се антериорно-постериорно значење ишчитава само на основу трајања непуне деценије мира која је смењена трајањем деветнаестог века, у овој координираној структури заправо је остварен симултани временски однос, будући да се може идентификовати временска тачка у којој је један временски период на прагу а други на измаку:

(2) Деветнаести је век био стигао на праг времена а непуна деценија мира у којој тек што је започела културна обнова Србије била је стигла на свој измак (Светлана Велмар-Јанковић, Врачар: 35);

Као додатни показатељи адверзативности у реченичној структури могу се јавити антонимске лексеме (3-4), много / мало, расти / падати. На исти начин као и код координираних копулативних реченица симетрија у конгруенцији [плусквамперфекат + плусквамперфекат] маркирана је 
антериорношћу у односу на консекутивне клаузе чији су предикати формализовани перфектом (3), а остварена је следећа конфигурација типова глаголске ситуације [ДОСТИГНУЋЕ - ОСТВАРЕњЕ - АКТИВНОСТ АКТИВНОСТ].

(3) Угледне и моћне пребеглице из Србије, на пример, бекством преко реке биле су изгубиле много од свог угледа а [биле су] пренеле мало од богатства, тако да се и углед крњио и богатство отапало (Светлана Велмар-Јанковић, Врачар: 131);

Знатно чешће него што је то случај код координираних копулативних реченица, симетрија глаголских облика [плусквамперфекат + плусквамперфекат] остварује се у координираним адверзативним двопредикатским реченицама, насталим асиндетским (6) или синдетским (4-5) синтаксичко-семантичким поступком везивања експлицирањем везника $a$. Поред симетрије остварене у конгруенцији глаголских облика, симетрија је забележена и у конфигурацији типова глаголске ситуације, те се у примерима (4-6) остварује [ДОСТИГНУЋЕ - [ДОСТИГНУЋЕ]]. ${ }^{16}$

(4) Вредност новца опет је била почела да расте а вредност главама [је била почела] да пада (Светлана Велмар-Јанковић, Врачар: 135);

(5) [...] Хаџи-Рувима је био предао Турцима српски митрополит а Петра Молера [је био предао] српски Господар (Светлана Велмар-Јанковић, Врачар: 83);

(6) Проти је било запало да путује и у Беч и у Петербург да сврати пажњу царева на српско питање, Молеру [је било запало] да у Земуну обавља силне послове који је требало да помогну и Србима и Проти (Светлана Велмар-Јанковић, Врачар: 74);

2.2.2. Као што примери регистровани у нашем корпусу показују, употреба плусквамперфекта у координираним адверзативним сентенцијалним

\footnotetext{
16 Важно је напоменути да семикопулативни фазни глагол у примеру (4) добија клаузалну допуну у виду немобилног презента, односно субординативног везника ДА и пунозначних глагола расти/ падати. Ранија истраживања показују да је у оваквим, формално комплексним, синтаксичко-семантичким структурама које се на нивоу реченице могу сматрати функционално јединственом јединицом носилац свих релевантних граматичких обележја као што су лице, број, род, време, начин управо семикопулативни фазни глагол (Antonić 2000: 96-97).
} 
структурама показује сличности, али и извесне разлике у односу на његову употребу у координираним копулативним реченицама. Најпре, (а) функција исказивања хронолошког тока догађаја, као и (a') сигнална функција антериорности забележене су и у овом типу реченица, али је (a") сигнална функција симултаности знатно чешћа него код копулативних реченица. Регистровану специфичност можемо објаснити првенствено посредством разумевања саме природе адверзативног односа. Наиме, копулативне форме називају се и реченице отворене структуре, будући да се појединачне предикацијске јединице могу низати до неограниченог броја, док се на адверзативне форме обично реферише термином реченице затворене структуре, ${ }^{17}$ што је условљено чињеницом да се само две предикацијске јединице могу наћи у адверзативном односу. У питању је, заправо, симетрија на плану садржаја будући да један ентитет најчешће доводимо у однос поређења, у овом случају по супротности, са другим ентитетом, или групом ентитета која се поима као целина, те су вишеструка поређења, односно поређења међу више од две јединице когнитивно онемогућена.

Притом, уколико плусквамперфекат конгруира са перфектом остварују ce (a) и (a') функција, док се у случају симетрије [плусквамперфекат + плусквамперфекат] остварује (а") функција. Као и у случају координираних копулативних реченица, предикације формализоване плусквамперфектом остварују се као глаголске ситуације типа остварења и достигнућа. Уз то, у овом типу реченица израженија је симетрија како у погледу конгруенције глаголских облика, тако и у погледу конфигурације типова глаголске ситуације, те се често реализују структуре [ОСТВАРЕњЕ - ОСТВАРЕњЕ] и [ДОСТИГНУЋЕ - ДОСТИГНУЋЕ].

\section{3. ЗАКЉУЧАК}

Анализом примера ексцерпираних из прозног текста који припада белетристичком функционалном стилу савременог стандардног српског језика, идентификоване су три функције које плусквамперфекат има у позицији предиката координираних копулативних и адверзативнних реченица, и то (а) функција исказивања хронолошког тока догађаја, (a') функција исказивања антериорности и (a") функција исказивања симултаности. Са становишта

\footnotetext{
${ }^{17} \mathrm{O}$ реченицама отворене и реченицама затворене структуре в. Пипер 2018.
} 
конгруенције глаголских облика, забележена је конгруенцијска веза плусквамперфекта са перфектом, као и симетрична конгруенцијска веза [плусквамперфекат + плусквамперфекат] и код копулатививних и код адверзативних реченица. Притом, као правилност можемо издвојити и то да ће плусквамперфекат остварити (а) и (а') функцију у случајевима када остварује конгруенцијску везу са перфектом, док ће функцију (a") остварити у случају симетричне конгуенцијске везе. Са становишта конфигурације типова глаголске ситуације, предикација формализована плусквамперфектом остварује се као остварење и као достигнуће, при чему је симетрија у конфигурацији израженија у координираним адверзативним реченичним структурама. Стога уочене правилности можемо сматрати једном од одлика успостављеног синтаксичко-семантичког односа координације.

\section{ИЗВОРИ}

Речник српскога језика. Нови Сад: Матица српска, 2011.

$$
\text { **** }
$$

Svetlana Velmar-Janković (2016). Vračar. Laguna.

\section{ЛИТЕРАТУРА}

Антонић, Ивана (2005). Синтакса и семантика падежа. У: Предраг Пипер и др. Синтакса савременога српског језика. Проста реченииа. Београд: Институт за српски језик САНУ; Београдска књига - Нови Сад: Матица српска. 119-300.

Антонић, Ивана (2006). О књизи и поводом књиге: Predrag Novakov. Glagolski vid i tip glagolske situacije u engleskom i srpskom jeziku. Novi Sad: Futura publikacije, 2005, 148. Јужнословенски филолог LXII. 376-390. [приказ]

Антонић, Ивана (2015). „Прилошке лексеме као индикатори значења изненадног појављивања у времену”. Грковић-Мејџор, Јасмина, Ружић, Владислава (Ур.). Лингвистичке свеске 10. Српски језик и његове норме (дијахроно-синхрони аспекти). 143-159.

Ивић, Милка (1958). „Систем личних глаголских облика за обележавање времена у српскохрватском језику”. Нови Сад: Годишњак Филозофског факултета, књ. 3. 139-152. 
Ивић, Милка (1980). „О значењу српскохрватског плусквамперфекта”. Зборник Матице српске за филологију и лингвистику. 23/1. 93-100.

Курешевић, Марина (2009). „Употреба претериталних времена у Српској Александриди". Београд: Научни састанак слависта у Вукове дане: Развојни прочеси и иноващије у српском језику. 38/1. 253-266.

Пипер, Предраг (2018). Напоредносложене реченице. У: Пипер Предраг, Алановић Миливој, Павловић Слободан, Антонић Ивана, Николић Марина, Војводић Дојчил, Поповић Људмила, Танасић Срето, Марић Биљана. Синтакса сложене реченице у савременом српском језику. 3590.

Поповић, Људмила (2012a). „Функције плусквамперфекта у савременом српском и украјинском језику”. Јужнословенски филолог LXVIII. 113145 .

Поповић, Људмила (2012б). Контрастивна граматика српског и украјинског језика: таксис и евидениијалност. Београд: САНУ. Одељење језика и књижевности. Српски језик у поређењу са другим језицима. Књига 3.

Танасић, Срето (2005). Синтакса глагола. У: Предраг Пипер и др. Синтакса савременога српског језика. Проста реченица. Београд: Институт за српски језик САНУ; Београдска књига - Нови Сад: Матица српска. $345-476$.

$* * *$

Antonić, Ivana (2000). „Aspekatska vrednost predikacije s faznim / modalnim glagolom na primeru rečenice s temporalnom klauzom”. Јужнословенски филолог. LVI 1/2. 93-101.

Antonić, Ivana (2001). Vremenska rečenica. Sremski Karlovci - Novi Sad: Izdavačka knjižarnica Zorana Stojanovića.

Klikovac, Duška (2008). „Iz problematike funkcionalnih stilova u srpskom jeziku”. U: Jezik i moć. Beograd: Biblioteka XX vek. 111-134.

Novakov, Predrag (2005). Glagolski vid $i$ tip glagolske situacije u engleskom $i$ srpskom jeziku. Novi Sad: Futura publikacije.

Radovanović, Milorad (1975). „Značenja i funkcije pluskvamperfekta u Romanu o Londonu Miloša Crnjanskog”. Novi Sad: Godišnjak Filozofskog fakulteta, knj. 18, sv. 1. 165-179.

Radovanović, Milorad (1990). „O narativnim glagolskim oblicima”. U: Spisi iz sintakse i semantike. Sremski Karlovci - Novi Sad: Izdavačka knjižarnica Zorana Stojanovića. 167-179. 
Ivona Z. Ilić

PLUPERFECT IN COORDINATE SENTENCES IN THE CONTEMPORARY STANDARD SERBIAN LANGUAGE: ON EVIDENCE FROM THE BELLETRISTIC FUNCTIONAL STYLE

\section{Summary}

This paper deals with the distributive and functional characteristics of the Pluperfect in the narrative discourse of the Standard Serbian language. In focus are coordinate copulative and coordinate adversative sentences in which Pluperfect has a predicate function. Special attention is devoted to the uses of tenses and Aktionsart in coordinate sentences. The author analyses the functions of the Pluperfect in this type of sentences as well as some of the regularities that can be considered as a feature of coordinate structures.

Key words: coordination, coordinate copulative sentences, coordinate adversative sentences, Pluperfect, Aktionsart 